\title{
AN ERROR ANALYSIS ON THE USE OF SIMPLE PAST TENSE AMONG THE SECOND SEMESTER STUDENTS MAJORING FOOD AND BEVERAGE STUDY PROGRAM AT BALIKPAPAN STATE POL YTECHNICIN 2015-2016
}

\author{
${ }^{1 *}$ Abdul Gafur, ${ }^{2}$ Farida \\ ${ }^{1,2}$ Dept of Food and Beverage, State polytechnic of Balikpapan \\ *e-mail:abdul.gafur@poltekba.ac.id
}

\begin{abstract}
The objectives of this study are (1) to identify and classify the errors of the Second Semester Students majoring Food and Beverage Study Program in Balikpapan State Polytechnic in using simple past tense, (2) to describe the frequency occurrence of the errors. The instrument used was a test on English simple past tense for high education level. The population of the study the Second Semester Students majoring Food and Beverage Study Program in Balikpapan State Polytechnic, which consisted of two classes. However, samples were used as the researcher could not cope with the whole population. The samples consisted of 50 students. Students errors identified in this study were categories into three types, namely, errors of omission errors addition and errors misformation. The result of the analysis shows that there were in all, 1234 errors among 50 students. The types of errors among the students in constructing and using English simple past tense consisted of 68 (5\%) errors of omission, $95(8 \%)$ errors of addition and $1071(87 \%)$ errors of misformation. From the highest to the lowest, the errors were: misformation, addition, and omission. The average number of errors made of all the students was $46 \%$. From the percentage, it can be concluded that the students' mastery in using English simple past tense was poor.
\end{abstract}

Keywords: Students, Errors, Simple Past Tense.

\section{Introduction}

Students' errors are very useful ways of showing what they have and have not learnt. Dubin F. and Olshtain E. (1986: 74) reported,: ... today errors are viewed as an integral part of the language-learning process from which we can gain very significant insight." It tells that errors are important to study in order to understand the process of learning. A study of learners' errors describes what problems the learners are having now and help the teacher to plan remedial work. In addition, the teacher should not see negatively as a sign of failure but see them positively as an indication of what the teacher still needs to teach. So, if the teacher tries to prevent students; errors, he/she never finds out what they do not know.

To make a good composition, the students must be able to master and apply the structure correctly, especially about tense used. In this case, the tense used is simple past tense. If they cannot do that, of course, errors will arise. Automatically their writing will cause misunderstanding for the readers, because the readers cannot receive the massage or expression of their idea well. Most of the students still find problems in using it, because of their limited mastery, especially the differences between regular and irregular verb. Therefore the writer wants to analyze the errors made by the students and tries to give solutions to overcome their problems. He chooses the title "An Error Analysis on the Use of Simple Past Tense among the Second Semester Students majoring Food and Beverage Study Program in Balikpapan State Polytechnic."

Based on the background of the study there are problems, which can be formulated after identifying the type errors, omitted among the Second Semester Students majoring Food and 
Beverage Study Program in Balikpapan State Polytechnic. follows:

The problem can be stated as

1. What analysis is to be described on the use simple past tense among Second Semester Students majoring Food and Beverage Study Program in Balikpapan State Polytechnic?

2. What analysis is to be described on the frequency occurrence of the errors made among the Second Semester Students majoring Food and Beverage Study Program in Balikpapan State Polytechnic?

\subsection{Definition of Error and Mistake}

Many linguists have defined differently what an error is based on their own concept. Fromkin and Rodman (1978: 361) states that the human brain is able not only to acquire and store the mental grammar, but also access that linguistic store house to speak and understand what is spoken, meaning they are against the grammatical rule of the language and result in unacceptable utterances, in second language learning they occur because the learner has not internalized the grammar of the second language. In order words, the student arise out of lack of competence, therefore errors are systematical. Furthermore, they make a distinction between errors, mistakes, and lapses.

According to Soetikno (1996: 187) contrastive analysis has in many case, failed to predict learning problems, despite the claim that contrastive analysis has not only predicated difficulties in the areas where the mother tongue and foreign differ but also in the case of linguistic features that are unknown in the sources language.

\subsection{Categories of Errors in Error Analysis}

To categorize error into classification based on the types or the sources of errors is not easy work. Many times error cannot be traced back into one source. More over, the boundaries between different sources of error many sometimes be unclear that the arbitrary classification decision unavoidable

According to the process editing written by Loarch in her book (1984: 181) the writer concludes that there are two categories of errors, global and local errors.Global errors are thus which affect the over all sentence organization significantly, while local errors are those affect single element (constituent) in a sentences.

\subsection{English simple past tense}

The simple past tense indicates that on activity or situation began and ended at a particular time in the past.

Example:

- I walked to school yesterday.

Sentence pattern of simple past tense:

Affirmative(+): $S+V 11+c$
(complement).

Example:

Negative (-): $S+$ did not + infinitive $+c$. Example:

- He did not see a film at Jaya theatre last night

Interrogative(?): Did $+S+$ infinitive $+c$ ? Example:

- Did he see a film at Jaya theatre last night?

The use of this tense is limited to indicate that an activity, state or occurrence in the past without indicate any connection with the "yesterday" is one of the safe time signals for this tense.

\section{Research Methodology}

The use of method in a research is very necessary, because it will be able to help a researcher to get data easily. There are some methods that can be used to do research. They are experiment, this survey method. And this survey method the research the method that was used was survey. It is a method used to describe phenomena of a case by taking its data that will be analyzed and generalized to the 
population of research through Descriptive to qualitative samples.

The case that was surveyed in this research was about phenomena of English simple past tense errors committed by the Second Semester Students majoring Food and Beverage Study Program in Balikpapan State Polytechnic.

\subsection{Population and Sample}

\subsubsection{Population}

Population is all individuals becoming subjects of research. Usually the number of population in the area of research is great. It must consider the ability of population. Because it will be influence whether the result of research is good or not.

The population in this research is the whole numbers of the Second Semester Students majoring Food and Beverage Study Program in Balikpapan State Polytechnic. There are two classes. Every class consists of 29 students. So the total numbers are 58 students.

\subsubsection{Sample}

Sample is part of population becoming subjects of research. The sample will be taken of the subjects or individuals in area of the research are great enough. It is too many to make data from all individuals in area of the research.

The data can be gotten from part of population by using technique or random sampling. It is technique of taking part of population or sample at random. It means that all individuals in the population get the some chance to be selected to become the member of sample.

Meanwhile the sample of this research is 50 students. In 1TB1, it took 25 students, and class 1TB2 took 25 students.

\subsection{Instrument of Research}

Instrument used to get data in this research was in the form of topics list used in the writing composition. The instrument used in the research should be appropriate with the variables of research. So in order to get data relating to each variable, the researcher used the form of topics list as instrument for asking the students to produce their language in the form of written language through writing composition spontaneously in the class.

\subsection{Technique Of Data Collections}

The technique used to collect data in this research was by giving a test of writing composition to the students. The purpose of giving the test was to ask the students to produce her/his language through writing an English composition spontaneously. It means that it does not give the opportunity to the students to look up his/her note.

The result of the student's work was needed to analyze her language, which has many kinds of errors. So in this case test did not measure the student's ability in the writing skill, but it analyzed the student's errors in producing their language in the written from in the aspect of English simple past tense.

\subsection{Data Analysis}

The data were the errors found in the sentences in the students writing. After the records had been collected, the data processing procedure was carried out.

According to the Carden's Model (1987:173) the first step in process if analysis is the identification of errors. After identifying the errors the total number of errors, made by the learners was counted, and the value each errors was 1 (one).

After the identification of the errors the researcher formed a reconstruction of the correction of the sentences in the target language, or on the other word, the researcher compared the original sentences and finally describe the differences.

\section{Results and Discussion}

\subsection{The results of Qualitative analysis}

The Second Semester Students majoring Food and Beverage Study Program in Balikpapan State Polytechnic, 
in using English simple past tense, did the analysis as an attempting to find out the errors mode. The analysis of the data as mentioned in before was done by the following two steps (Qualitative and Quantitative). It is included identifying the errors and classifying the errors.

\subsubsection{Identifying the Errors}

This was done identifying and counting the numbers of errors, which appeared in the students answer sheets. As in had done, the test in English simple past tense, which consists of 50 items, was conducted to 54 subjects. Most of the items in the test were answered (which were included in the errors of omission). Besides, the researcher also described the number of errors (wrong answer) for each sentence on the test as an integrated part of the description of the frequency of occurrence of the errors.

\section{- Errors of Omission}

They are indicated by the absence of one or more items that must appear in a well-formed sentence. From the data analysis, errors of omission, which could be identified in these studies, are:

1) Omission of "not" in negative simple past tense.

2) Omission of the simple past tense, and

3) Blanks or unanswered items.

\section{- Errors of Addition}

The second type of errors in this study is errors of addition. As it has been mentioned in advance, errors of addition are characterized by the presence of one or more items that must appear in wellformed sentences. Identified in this study include:

1. Addition of "was/were" on nominal sentences

\section{- Errors of Misformation}

These kinds of Errors are characterized by the use of incorrect form morpheme or structure. While in errors of omission, the items is not supplied of all, in errors of misformation the learners supply something although it is in an incorrect form. The errors of miss formation identified in this study are:

1. Misformation of "V1 to be VII".

2. Misformation of auxiliaries "did, was, were.

3. Misformation of "to be "(was/were)

4. Misformation of change to negative (-) and interrogative, (?) sentence

5. Misformation of "did" and "was/were" in the interrogative (?)

\subsection{Result of Quantitative analysis}

Quantitative analysis was done as the coming process of identifying and classifying the errors, in the attempt to answer research question as stated in chapter I, especially concerning with the students errors and problems in using English simple past tense.

Students on the test did this analysis on the basic of competition on the percentage of errors mode. Then, from the errors percentage, it can also be inferred, which aspects/items of English simple past tense? We found to be more difficult than the other. Therefore, in this study a certain item is identifies, as a difficult item is 45 $\%$ or more if the students make errors.

Table 1: Students' mastery level in terms of Mastery

\begin{tabular}{|l|l|}
\hline \multicolumn{1}{|c|}{ Errors } & Level of Mastery \\
\hline $8 \%-15 \%$ & Very \\
$16 \%-30 \%$ & Good \\
$31 \%-45 \%$ & Good \\
$46 \%-50 \%$ & Fair \\
$51 \%-100 \%$ & Poor \\
& Very \\
& Poor \\
\hline
\end{tabular}

It found that in this study the students had difficulty in using English simple past tense since they still made many errors.

There are 23 items out of 50 items having error percentage $45 \%$. Thus, it means that the student's level of mastery is still poor since they still faced difficulties 
in certain items of simple past tense. It terms of errors types, the frequency occurrence of each error type is provided in table below:

Table 2: Frequency occurrence of each error type.

\begin{tabular}{|l|c|c|}
\hline $\begin{array}{c}\text { Type of } \\
\text { Errors }\end{array}$ & $\begin{array}{c}\text { Number of } \\
\text { Errors }\end{array}$ & $\begin{array}{c}\text { Percentage } \\
\text { of errors }\end{array}$ \\
\hline Omission & 68 & $5 \%$ \\
Addition & 95 & $8 \%$ \\
Misformation & 1071 & $87 \%$ \\
Misordering & - & - \\
TOTAL & $\mathbf{1 2 3 4}$ & $\mathbf{1 0 0 \%}$ \\
\hline
\end{tabular}

Table above shows that out of 1234 errors, there are $68(5 \%)$ errors omission, $95(8 \%)$ errors of addition, and 1071 (87 $\%$ ) errors miss formation, there is no error of miss ordering.

The percentage of each type or errors above was calculated by using the formula:

\section{$\frac{\text { Number of errors types }}{\text { Terms of eac? error types }} \times 100 \%$}

\subsection{Discussion}

This study, as it has been mentioned in advance, aimed at finishing out weather the students have problems in using English simple past tense.

The data analysis of the test on simple past tense show that errors of misformation reached the highest frequency, followed by errors of addition, and errors or omission, it was found that there is no error of misordering in this study. Further analysis concerning the use of simple past tense in terms of each always of the items shows that misformation errors were always of the highest frequency.

The researcher thinks that they happened because most of the students still have problems especially with the use of tense, auxiliaries, and special patterns on the simple past tense.

\section{Conclusion}

From the analysis it can be inferred that the students can face some problems in using and constructing the simple past tense especially dealing with words and patterns, the students' mastery on English simple past tense is poor, based on the research, the teacher is able to give the real understanding to the students, but the students must obtain exercise more often, the student's concentration can be focused to the practice, the writer hopes that data analysis can motivate the students to study more diligent.

\section{Suggestion}

The result of this study are meant indirect significantly to both the lecturers and students. For the lecturers, the student's errors show how far they have understood the lesson and what remains for them to learn. By studying the students' errors and knowing the areas of difficulty, the lecturer will get the clear picture of the student's knowledge of language, particularly in using English simple past tense. Furthermore, the lecturer will be able to select the most appropriate technique and the teaching materials as well. Those can be done if the teachers of English pay more attention to the problems on English simple past tense and give more emphasis in their teaching process.

\section{References}

[1]Carden, Guy. (1987). Anaphora and Conceptual Structure. Chicago: University of Chicago Press

[2]Dubin, F. \& Olshtain, E. (1986). Course Design: Developing Programs and Materials for Language Learning. Cambridge: Cambridge University Press.

[3]Fromkin, Victoria \& Rodman, Robert. (1978). An introduction to language, 2nd ed. New York: Holt.

[4]Lorch, Sue. (1984). Basic writing : a practical approach.Boston: Little Brown

[5]Soetikno, I. (1996). Analisis Wacana. Jakarta: Gramedia Pustaka Utama 